\title{
A New Historical Approach to Midnight's Children
}

\author{
Yang Gao \\ Tan Kah Kee College, Xiamen University, Zhangzhou, China \\ 148253908@qq.com
}

Keywords: New Historicism, Midnight’s Children, Salman Rushdie

\begin{abstract}
As a representative writer of postcolonial literature, Salman Rushdie gained his reputation for his second novel Midnight's Children, the best Booker Prize winner of all time. The novel is set in the context of actual historical events as with historical fiction. Most critics interpret the novel from the perspective of postcolonialism or postmodernism. Meanwhile, New Historicism provides a new approach to understanding this fiction. Therefore, this paper aims to reveal the relationship between national history and personal experience in Midnight's Children by applying the doctrine of New Historicism, which will be done in two parts. The first part analyzes the Historicity of the book, and the second part explores Textuality of History reflected in the book.
\end{abstract}

\section{Introduction}

New Historicism is an approach to literary theory and criticism as well as sociological theory. It was coined by Harvard English Professor Stephen Greenblatt, who is also regarded as the major founder of New Historicism [1]. The theory arose in the 1980s and gained widespread influence in the 1990s. In contrast with traditional Historicism and Formalism, New Historicism aims to reintroduce the concept of history into literary studies by paying close attention to the historical context of literary works. It attempts to understand literary works through their cultural context and to understand intellectual history through literature. As Louis A. Montrose argues in Professing the Renaissance: The Poetics and Politics of Culture: "New Historicism is new in its refusal of distinctions between 'literature' and 'history', between 'text' and 'context'" [2], New Historicism valuates how the work is influenced by the time in which the author wrote it and how the work changes people's interpretation of history. So to understand the work through its historical context and to investigate the intellectual history and cultural history through literature is the primary work of New Historicists. This paper will try to interpret Midnight's Children, Indian-English writer Salman Rushdie's masterpiece, through basic approach of New Historicism by analyzing the historicity of text and the textuality of history.

\section{The Historicity of Text}

New historicists believe that historical texts, such as history books, novels, literary works, documents and folklores, are influenced by the time in which the author wrote it. Thus, a literary work should be regarded as a product of the time, place, and historical circumstances of its composition. Moreover, in the process of writing, historical events are interpreted by writers with their personal experiences and opinions. Therefore, it is necessary to examine writers' psychological background, the social sphere, and the books and theories that may have influenced them.

\subsection{Birth}

Salman Rushdie is a British Indian novelist and essayist who was born on June 19, 1947, the same year Indian became an independent country. On August 15, 1947 India commemorated the nation's independence from the British Empire, which is the most significant date in Indian history, that's almost exactly three months after Rushdie's birth. This coincidence may offer Rushdie hints and inspiration to the writing of Midnight's Children and is further enhanced in his novel, as the narrator, who is also the chief protagonist of the novel, was born at the stroke of midnight on August 
15, "at the precise instant of India's arrival at independence"[3]. Together with Saleem, there are other a thousand children, who were born at the same night. They are called midnight's children and they are closely related to each other, as well as to the nation's destiny. Like a newly born life, the newly born independent country had to come across lots of challenges. One of the most serious problems is that the South Asian subcontinent, after nearly one hundred years of colonial rule, while coming to an end, was divided into two independent dominions - India and Pakistan, and was given to two sovereign governments, largely based on district-wise Hindu or Muslim majorities. There were conflicts between Muslims and Hindus before the Partition, like the one on August 19, which caused 3000 dead; and Street violence between Muslims and Hindus in Bombay on September 4, 1946. So the period that immediately followed independence proved troublous. There are political and social tensions between Hindus and Muslims after the Partition: two wars over Kashmir, and one over the creation of an independent Bangladesh. All these events were depicted in the novel and made great impacts on the plot. 1947 is an eventful year because other important historical events took place in this year, such as Hindus and Muslims clash in Punjab; Indo-Pakistani War of 1947, and Massacres and migrations in Punjab. Therefore, historical background had a huge influence on the writing of Midnight's Children. Basically, Midnight's Children is regarded as historical fiction as it is set in the context of actual historical events.

Rushdie was born in 1947, an eventful year. The time when he was born and the later years when he was raised was a time of transition and transformation of his nation, which had greatly shaped his ideology and understanding of history. Some critics argue that Midnight's Children is an autobiography of Rushdie as he wrote in the novel: "I had been mysteriously handcuffed to history, my destinies indissolubly chained to those of my country" [3]. Rushdie was born in Bombay, then British India, now Mumbai; so much of his fiction is set on the Indian subcontinent, including Midnight's Children. This novel deals with India's transition from British colonialism to independence, so it is considered as an example of postcolonial literature.

\subsection{Family Background}

Rushdie was born into a wealthy family of Kashmiri descent, the only son of the family, so does the protagonist and narrator of the story - Saleem Sinai. Rushdie's father is a successful businessman who graduated from the University of Cambridge, which guaranteed Salman the best education. His childhood was happy and he was always surrounded by books. He wanted to be a writer when his is only five years old and was sent to England at age fourteen to attend Rugby, a private school. Later he went to King's College, University of Cambridge, and received his master's degree in history. Because of his educational background, Rushdie became interested in and sensitive to history. The works of Salman Rushdie often focused on outrages of history, such as Midnight Children and Shame.

After graduating from the University of Cambridge in 1968, Rushdie lived with his family who had moved to Pakistan in 1964 after the Partition, just as the protagonist Saleem and his family does in the novel. Pakistan, officially the Islamic Republic of Pakistan, was created in 1947 as an independent homeland for Indian Muslims. As Rushdie was born into a Muslim family, it's better for them to move back to Muslim Pakistan, for Hindu - Muslim riots break out along both the western and eastern borders. There's a reflection in the novel that Saleem was revealed that his parents were not his biological parents because he was shifted at birth. His father was so angry that he sent Saleem to his uncle in Parkistan and later war breaks out between India and Pakistan, so they all moved to Parkistan. Four years later, his father - Ahmed Sinai suffered heart disease, so they move back to Bombay and then the Sino-Indian War broke out. After the war, they left Bombay and went to Karachi, Parkistan again. These constant shifts of places and time attribute to Rushdie's early life moving between his hometown and England.

Rushdie returned to England and worked as a copywriter for an advertising agency. It was this experience at the agency that inspired his writing of Midnight's Children and catapulted him to literary notability.

Moreover, Rushdie is from a family of Kashmiri descent as his grandparents were born and 
raised in Kashmir. He is intimately familiar with the area and spent summers there. So he is very conscious of his Kashmiri diaspora, people who have migrated out of the Kashmir Valley and their descendants. His 2005 novel Shalimar the Clown is set for the most part in Kashmir, trying to raise world's awareness of this lost paradise being torn back and forth by the military power of two warring nations. In Midnight's Children, Rushdie showed great concern on his ancestral home. There's no doubt that he treasure this place, as he wrote in the novel: "There is the future to think of.' The honeymoon is to be in Kashmir." "I began to dream repeatedly of Kashmir"[3]. To Rushdie, Kashmir was like a paradise, "I floated in shikaras and climbed Sankara Acharya's hill as my grandfather had; I saw lotus-roots and mountains like angry jaws”[3]. He dreamed of the peaceful life and coexistence of Hindus and Muslims in Kashmir. He felt it was his responsibility to introduce his hometown Kashmir to the world and tell the story of Kashmir about its history and sufferings. The boatman Tai once said: "'Kashmiris are different. Cowards, for instance. Put a gun in a Kashmiri's hand and it will have to go off by itself - he'll never dare to pull the trigger. We are not like Indians, always making battles.'”[3] Kashmir represents the long-lost peace both in India and Parkistan. Kashimiris are against war because they long for peaceful life. However, they all fell victims of war. Even now, there are still conflicts in this area. By revealing the contrast between Kashmir before war and after war in Midnight's Children, Rushdie states his resentment against conflicts and wars.

\subsection{Religious beliefs}

Rushdie came from a liberal Muslim family, and he admitted that he was "shaped by Muslim culture more than any other" in an interview in 1989 [4]. However, he was educated in England, a place offers the best western education. Because of the interconnection and interdependence of his family background and educational background, and the blending of Muslim culture and British Christian Culture, he regarded himself as, in a sense, a lapsed Muslim, and he said "My point of view is that of a secular human being. I do not believe in supernatural entities, whether Christian, Jewish, Muslim or Hindu."[5] And now he called himself a "hardline atheist"[6], just like the boatman Tai in the novel. As Tai argues: "I saw that Isa, that Christ, when he came to Kashmir. Smile, smile, it is your history I am keeping in my head. Once it was set down in old lost books. Once I knew where there was a grave with pierced feet carved on the tombstone, which bled once a year."[3], he is a witness of history, from ancient time when Kashmir is a place of pureness, to its colonized present. Even though Tai is a Muslim, he understands the existence of different religions and cultures. This is what Rushdie had observed and experienced in his life and reflected in his work Midnight Children. "Soon the English sahibs would arrive and Tai would ferry them to the Shalimar Gardens and the King's Spring, chattering and pointy and stooped." The mysterious boatman Tai ferries the Westerners/colonizers to local India/ colony, just like Salman ferries culture, religion and ideology of Indian subcontinent to the West/world by writing Midnight's Children.

The blending of family background and educational background has huge impact on one's identity including culture and religion. Rushdie is an Indian born British writer, from a Muslim family, while the protagonist's grandfather Aziz is an Indian born doctor who received German education. After returning from Germany, Aziz hit his nose while trying to pray, so "he resolved never again to kiss earth for any god or man". However, this decision "made a hole in him, a vacancy in a vital inner chamber, leaving him vulnerable to women and history."[3] The hole symbolizes identity loss and culture vacancy as well as religion blurring and dissolving. So does the writer Rushdie, from a liberal Muslim to an atheist. As a novelist who lives in Bombay, Karachi, London and New York, Salman Rushdie exemplifies a hybrid identity in what he writes.

\section{The Textuality of History}

Personal experiences of the characters in Midnight's Children are closely related to the national history of Indian and Parkistan. It is set in the context of actual historical events as with historical fiction. The protagonist symbolizes the country Indian as they were both born at the same time and the writer made this very clear in his writing. Every time there's something going on in India, his 
nose senses it and he does not feel comfortable. He does not only experience historical events, but also takes part in it. For example, he assists his uncle General Zulfikar as he makes the revolution against the Pakistani government, which made General Ayub Khan the second President of Pakistan. There are historical events like Indo-Pakistani War of 1947, Indo-Pakistani War of 1965, Indo-Pakistani War of 1971 and Sino-Indian War in 1962. Rushdie depicted these events and made judgments through the expression of characters' opinions. For instance, Rushdie is against Sino-Indian War and thought it wasn't a good time for war because people are still suffering. As a newly born country, India has a long way to go before it achieves prosperity. However, the president then was quite optimistic about the war, as Rushdie wrote "The disease of optimism" "optimism about the war grew as fat" "optimism-fever". He even argued "this country is finished. Bankrupt. Funtoosh.'”[3]

Moreover, almost all Saleem's family members can be seen as embodiments of history. Saleem's grandfather Aadam Aziz has a big nose and he is very sensitive to historical events because of the nose. Saleem's son Aadam Sinai, born at the moment of the Emergency, which is also a very important day in India's history, can be seen as another Saleem Sinai and the continuation of the history. As Riemenschneider says, "In Rushdie's book there is virtually no event which is not given an individual as well as an historical meaning." [6] So personal experience and life are linked closely to history, and they are the embodiments of history.

As for Aadam Aziz, Saleem's grandfather, he can also be considered as an embodiment of history. First of all, he has a very unique nose, which can sense history. He is in Amritsar on April 13th, 1919, when the Jallianwallah Bagh massacre occurs. He does not only witness it, but also experiences it and even senses it. On that day, when he is in the street, he realizes that something terrible is going to happen because he feels "very scared, because his nose is itching worse than it ever has." [3] We can say that he is the exact embodiment of this public event as he can sense every detail of it. "Aziz penetrates the heart of the crowd, as Brigadier R. E. Dyer arrives at the entrance to the alleyway, followed by fifty crack troops...As the fifty-one men march down the alleyway a tickle replaces the itch in my grandfather's nose"[3]. Every movement has a reflection to him, and every tiny changes of his body suggest the steps of the event. While the fifty-one men "enter the compound and take up positions...the tickle mounts to unbearable intensities"[3]. As the event goes on deeper, Aadam responses more fiercely. Finally, "the sneeze hits my grandfather full in the face...when Brigadier Dyer issues a command". Aziz "sneezes and falls forward, losing his balance, following his nose and thereby saving his life.”, which reflecting what Tai has said to him once: "A nose like that, little idiot, is a great gift. I say: trust it. When it warns you, look out or you'll be finished. Follow your nose and you'll go far"[3].

However, not only Saleem himself has some kind of relationship with India history and embodies India's historical events, his family is closely related to it as well. Almost all his family members are the embodiments of varies kinds of historical events. Aadam Aziz has been Naseem Ghani's doctor for a long time, but he has never seen her, to be exactly, he has never seen her face. Naseem's father does not allow Aadam to do so because her daughter is a decent and unmarried girl. So Doctor Aadam is permitted to exam Naseem through a "perforated sheet". As Naseem never stop contracting illness and each time on different parts of her body, the "perforated sheet" moves all over her body thus enables Aadam know her body very well. However, there is one exception. He never has a chance to see her face because she never contracts illness in her head or face. But when it is November 11th, 1918, "on the day the World War ends, Naseem developed the longedfor headache.” [3] Thus, finally, they see each other, for the first time

Saleem's son, Aadam Sinai, can be seen as another embodiment of history. Even when Aadam is on his way to the world, he is linked to historical events. "while Parvati pushed in the ghetto, J.P. Narayan and Morarji Desai were also goading Indira Gandhi, while triplets yelled push push push the leaders of the Janata Morcha urged the police and Army to disobey the illegal orders of the disqualified Prime Minister, so in a sense they were forcing Mrs. Gandhi to push” [3]. The birth of Aadam seems to be the birth of a historical event. As he is coming out of his mother's body little by little, the event goes on step by step. “(Aadam's) head is out, the triplets screeched, while members 
of the Central Reserve Police arrested the heads of the Janata Morcha, including the impossibly ancient and almost mythological fugures of Morarji Desai and J.P. Narayan” [3]. And finally Aadam pops out, it is the time when "all over India policemen were arresting people... When the three contortionists had washed the baby and wrapped it in an old sari and brought it out for its father to see, at exactly the same moment. The word Emergency was being heard for the first time.” [3]. It is not a coincidence. Rushdie does this on purpose. He wants to relate personal experience and historical event and sometimes he even shapes history to fit personal life. It is an act that "creates personal meaning from history, assigning historical events significance in relation to himself as an individual” [8].

Saleem describes his son's birth in almost the same way as he describes his own. "I was born in the city of Bombay... once upon a time. No, that won't do, there's no getting away from the date: I was born in Doctor Narlikar's Nursing Home on August 15, 1947. And the time? The time matters, too. Well then: at midnight. No, it's important to be more... On the stroke of midnight, as a matter of fact. Clockhands joined palms in respectful greeting as I came. Oh, spell it out, spell it out: at the precise instant of India's arrival at independence, I tumbled forth into the world."[3] While he describes his son's birth, he uses almost the same words and sentences. "He was born in Old Delhi... once upon a time. No, that won't do, there's no getting away from the date: Aadam Sinai arrived at a nightshadowed slum on June $25^{\text {th }}, 1975$. And the time? The time matters, too. As I said: at night. No, it's important to be more... On the stroke of midnight, as a matter of fact. Clockhands joined palms. Oh, spell it out, spell it out: at the precise instant of India's arrival at Emergency, he emerged."[3] By using almost the same words and sentences describing the two character's birth, Rushdie emphasizes the resemblances between Saleem Sinai and Aadam Sinai. They are not only born important, but also "mysteriously handcuffed to history", and their "destinies indissolubly chained to" [3] their country. Aadam Sinai, to some extent, plays the same role as Saleem Sinai does. He will be the embodiment of the nation as well. The similarities between them indicate that Aadam is the continuation of Saleem and their family, even the continuation of India's history, just as Saleem says: "just the same, as my time of connection neared its end, his began."[3]

However, Aadam Sinai is not the exact duplicate of his father. There are differences between them at the same time. At the time when Saleem was born, "outside the window, (there are) fireworks and crowds"; while his son was born, "across the country, silence and fears."[3] Because they belong to different generations, they have different positions in India's history. Saleem is born when India becomes independent and gets rid of the British rule. "India itself, and the generation of Indians who grew up in the new nation called India, are experiencing their own crisis of identity."[8] The colonization is over and people in India become the master of their own nation. So it is a new start for everyone as well as the nation, and a time full of hope and future. People have dreams and also have passions on their dreams. However, it seems idealistic and unrealistic. Things changes after colonization, so do people in India. "We, the children of Independence, rushed wildly and too fast into our future"[3]. Whereas Aadam is "Emergency-born", he is "already more cautious, biding his time" [3] Though he will be impossible to resist when he acts, Saleem still sees hope from his son. "Already, he is stronger, harder, more resolute than I: when he sleeps, his eyeballs are immobile beneath their lids. Aadam Sinai, child of knees-and-nose, does not (as far as I can tell) surrender to dreams"[3]. Time changes, generations change, and the task given by history changes. We need different person to represent or embody the nation. And Saleem and Aadam are the embodiment of the nation in different times.

In all, personal experiences and historical events are closely linked and personal experiences are the embodiment of historical events. What's more, sometimes personal experiences can affect history and in a way change and shape history as the novel suggests. Thus the relationship between personal experiences and history is very intricate and interactive, they could influence each other.

\section{Conclusion}

By analyzing the historicity of text through exploring the author's birth time, family background, educational background and religion, and by analyzing the textuality of history through focusing on 
the historical events depicted in the novel, this paper provides a New Historicism approach to interpreting Midnight's Children. Rushdie's Muslim and pluralcultural identity makes strong impact on the writing of Midnight's Children. Personal experience and historical events are closely related to each other in a way that historical events influence the writer's personal experience and the personal experience of the characters in the novel represent historical events.

\section{References}

[1] Greenblatt, Stephen (2007). Learning to Curse. Routledge. p. 197.

[2] Veeser, H. Aram. Ed. The New Historicism. New York: Routledge, 1989 p20

[3] Rushdie, Saleem. Midnight’s Children. New York: Random House, 2006.

[4] Meer, Ameena (1989). "Interview: Salman Rushdie". Bomb. 27 (Spring). Retrieved 22 March 2015.

[5] "Fact, faith and fiction". Far Eastern Economic Review. 2 March 1989. p. 11.

[6] "Bill Moyers on Faith \& Reason . Bill Moyers and Salman Rushdie . June 23, 2006 - PBS".

[7] Riemenschneider, Dieter. "History and the Individual in Salman Rushdie’s Midnight's Children and Anita Desai’s Clear Light of Day.” Kunapipi. 6:2 (1984): 53-66.

[8] Reder, Michael. "Rewriting History and Identity: The Reinvention of Myth, Epic, and Allegory in Salman Rushdie’s Midnight’s Chilren.” M. Keith Booker, ed. Critical Essays on Salman Rushdie. New York: G. K., 1999. 225-250. 